\title{
Investigating Pre-service Teachers' Oral Performance Anxiety in Islamic and Asian Civilisations Contents
}

\author{
Mimi Rita@Aishah \\ binti Tajuddin \\ Universiti Utara Malaysia \\ Sintok, Malaysia \\ aishah.tajuddin@gmail.com
}

\author{
Aizan bin Yaacob \\ Universiti Utara Malaysia \\ Sintok, Malaysia \\ aizan904@uum.edu.my
}

\author{
Faizahani Ab. Rahman \\ Universiti Utara Malaysia \\ Sintok, Malaysia \\ faizahani@uum.edu.my
}

\begin{abstract}
Oral performance skills are important for the preservice teachers as part of the professional requirement for their job specifications as future educators. Thus, in presentation skill, the pre-service teachers might encounter oral performance anxiety which has positive and negative impacts on the preservice teachers. A step of viewing the pre-service teachers' anxiety was taken by giving them survey questions called OPAS (Oral Performance Anxiety Scale). The constructs given might give the information on which construct that the pre-service teachers feel anxious in oral performance. Oral performance anxiety can be defined along test anxiety (TA), fear of negative evaluation (FNE) and communication apprehension (CA). Specifically, the study examines oral performance anxiety associated to the sub-constructs namely TA, FNE and CA. Data for this study was obtained through a survey questionnaire called OPAS that was administered to 73 pre-service teachers in Institute of teacher education to investigate their oral performance anxiety prior to the oral performance in Islamic and Asian Civilisations contents. Findings suggest that most of the students experienced the different levels of oral performance anxiety from different sub-constructs. The lecturers will have the awareness about the process of the oral performance skills defined in the constructs of anxiety.
\end{abstract}

Keywords-oral performance; anxiety; test anxiety (TA); fear of negative evaluation (FNE) and communication apprehension (CA).

\section{INTRODUCTION}

The Ministry of Malaysia emphasises the balance between both knowledge and skills (ilmu) as well as ethics and morality (akhlak)[1]. In Malaysia Education Blueprint [1] insisted the balance of akhlak and ilmu or good morality and knowledge. As a Muslim believer, one of the ways to inculcate good morality and a source of knowledge was through Islamic teachings. Moral comes from the Prophet Muhammad role model. The knowledge comes from the Holy Book- Al Quran that comprises the knowledge on many aspects for example how to do trade, the knowledge on how the human beings were formed, the knowledge of marriage and divorce and a lot more that build Muslims' civilization. As a result, students need to be given knowledge about
Islamic and Asian Civilizations and they were expected to give oral presentation on that respective contents.

In an oral presentation, students usually faced anxiety in presenting their facts [2]. Furthermore, oral presentation anxiety faced by most of the second language learners. The learners feel anxious when they have to speak in English. In relation to oral presentation, the learner faced more anxious. "Standing in front of a group and presenting a talk can be a daunting task for even the most confident of us, and even more so for language learners"[3]. [4] study on anxiety on public speaking when the existence of the audience become one of the factors on the presenters' anxiousness.

This study aims to identify the pre-service teachers' levels of performance anxiety in terms of test anxiety (TA), fear of negative evaluations (FNE) and comprehension anxiety (CA).

\section{A. Affective Filter Hypothesis Theory}

Affective Filter Hypothesis theory was associated with oral performance anxiety. The natural approach to second language learning linked with the Affective Filter Hypothesis theory[5]. The students' presentation is assumed to be low because anxiety interferes presentations[6].

\section{B. Oral Performance Anxiety}

Oral performance anxiety was a common feeling of the presenters in an oral presentation. Students usually avoid if they have to present in front to speak on certain topics. In particular, if the topics are not familiar to them like the Islamic and Asian Civilizations. New vocabulary would be introduced and some of the terminologies are not common to their routine of learning English for so many years of learning the language. Most of them took English for 11 years at least; six years in primary schools and 5 years in secondary schools. A few studies made that supported anxiety phenomenon exists in presenters and how to overcome it [7][8][9]. Thus, there was a need to survey on the pre-service teachers' oral performance anxiety before planning a strategy to overcome the anxiety phenomenon. 


\section{Methodology}

Survey methodology was used for this case study in Institute of Teacher Education in Malaysia. The survey questionnaire was adapted from Foreign Language Classroom Anxiety Scale (FLCAS) questionnaire by [9][6]. The adapted version of FLCAS was called OPAS (Oral Performance Anxiety Scale) to suit the current study. The survey questions were adapted to extend the research from foreign language anxiety to oral performance anxiety.

The original questionnaire with 33 constructs was reduced to 26 constructs. Constructs number 4, 6, 21, 25, 29, 30, and 32 were omitted because the constructs were not related to oral performance. The research by [9][6] identified three performance anxiety: 1) test anxiety (TA); 2) communication apprehension (CA); and 3) fear of negative evaluation (FNE). The FLCAS questionnaire had stated items number 2, 9, 18, 19, 24 and 27 were examples of TA. Items number 4 and 29 as a statement identifying CA. Items number 7, 13, 23, 25 and 31 were the examples of FNE for the types of performance anxiety as stated in the original questionnaire.

Whereas, the OPAS survey questionnaire was to find out the pre-service teachers' anxiety levels on test anxiety (TA), communication apprehension (CA), and fear of negative evaluation (FNE) in oral performance. The adapted version has 26 items; 9 items identifying CA (item number 1, 3, 4. 10, $12,15,18,23$, and 26); 9 items identifying TA (item number $2,6,7,8,16,17,19,21$, and 24); and 8 items identifying FNE (item number 5, 9, 11, 14, 13, 20, 22, and 25). The rationale of identifying the levels of the anxiety was to allow more investigation on the oral performance anxiety among the preservice teachers.

\section{A. Validity and reliability}

Validity and reliability of the questionnaire were pursued on construct validity and reliability test. Construct validity of the questionnaire was required because of the adaptation of the questionnaire. The questionnaire was adapted from [6] so, validity was required in this research as a tool to investigate the rationality and consistency in conducting this research.

Validity measures what it was supposed to measure[10]. Construct validity was used to validate the questionnaire because [6]also used construct validation procedures for their study. Construct validation procedures involve testing a scale not only one phenomenon (anxiety) but also explore the relationship with other related constructs (test anxiety, communication apprehension, and fear of negative evaluation). Construct validity involves testing a scale, not against a single criterion but conforms theoretically derived suggestions regarding the nature of the fundamental construct[10][11]. This study wished to conform the anxiety phenomena on the theoretical suggestions through the constructs.

Beside construct validity, internal reliability had also being pursued in this study. Rationality of adapting Foreign Language Classroom Anxiety Scale (FALCAS) to Oral Performance Anxiety Scale (OPAS) was because FALCAS demonstrated high internal reliability in achieving an alpha coefficient of .93 with all items constructing significant corrected item-total scale correlations. $r=.83(\mathrm{p}<.001)$ after test and re-test the constructs over eight weeks[6]. The OPAS questionnaire had a pilot testing on 42 TESL pre-service teachers to test the reliability in the questionnaire. The result was .960 as stated in table 1 .

\section{TABLE 1 RELIABILITY STATISTICS}

\section{Reliability Statistics}

\begin{tabular}{|r|r|r|}
\hline Cronbach's Alpha & $\begin{array}{c}\text { Cronbach's Alpha } \\
\text { Based on } \\
\text { Standardized Items }\end{array}$ & N of Items \\
\hline .960 & .928 & 26 \\
\hline
\end{tabular}

The reliability test for the adapted questionnaire was a high alpha coefficient. The statistic used to test reliability was alpha coefficient. Cronbach's coefficient alpha was available using SPSS. [10]wrote $\mathrm{r}=.7$ was acceptable and $\mathrm{r}=.8$ was preferable. $\mathrm{R}=.8$ was considered the high degree of reliability with internal consistency[12]. After the pilot testing result, the current study presents the Cronbach's coefficient alpha value of .96 to show reliability with internal consistency. The pilot testing was administered for reliability test to the pre-service teachers using OPAS questionnaire. The reliability test was administered before the actual survey to ensure the reliability of adapted version of the questionnaire.

\section{B. Participants}

73 respondents were selected using purposive sampling. In the purposive sampling, the participants were selected from Teaching English as a Second Language programme.

\section{Method of data gathering}

The data were collected to achieve the research objective that was to find out the anxiety levels of the pre-service teachers in oral performance anxiety of Oral Performance in Islamic and Asian Civilisations (OPIAC). The survey will be administered using Oral Performance Anxiety Scale (OPAS) to the participants to investigate anxiety. This survey was to perceive or foresee TESL pre-service teachers' anxiety in oral performance before conducting OPIAC strategy. The survey has the opportunity to build up a background that facilitates the process of organizing data[13].

Before the survey, a pilot testing for reliability test with 42 TESL pre-service teachers was administered. Below were the data collection procedures for the OPAS survey in Diagram 1. Diagram 1 was OPAS survey procedures. Step 1, an adaptation of Foreign Language Classroom Anxiety Scale (FLCAS) questionnaire to Oral Performance Anxiety Scale (OPAS) questions. Step two, pilot testing of the questionnaire to get the reliability of OPAS to two classes of TESL consists of 42 pre-service teachers. Step 3, OPAS survey of Oral Performance in Islamic and Asian Civilisations (OPIAC) anxiety using OPAS questions. The respondents were from 73 TESL pre-service teachers. The OPAS survey was conducted 
to collect data on identifying the levels of anxiety in oral performance in Islamic and Asian Civilisations.

\section{- Adapted FLCAS Questionnaire}

\section{- Pilot Test}

\section{- OPAS Survey}

Fig. 1. Data collection procedures from OPAS survey

\section{Methods of data analysis}

The analysis technique for the survey on Oral Performance Anxiety Scale (OPAS) was through a survey questionnaire. The data was analysed based on the chosen constructs namely test anxiety (TA), fear of negative evaluation (FNE), and communication apprehension (CA) from the pre-service teachers' (OPAS) survey. The descriptive statistics were used to tabulate the data using SPSS version 21.

The analysis of the survey was to identify the pre-service teachers' level of performance anxiety in terms of test anxiety, fear of negative evaluations and comprehension anxiety. The descriptive analysis will be tabulated for the OPAS survey. Descriptive data analysis was done on predetermining constructs for anxiety: test anxiety (TA), fear of negative evaluations (FNE) and comprehension anxiety (CA). The analysis was organized to all the 26 constructs in the questionnaire that already set the questions related to TA, FNE, and CA. Means of each construct was tabulated to represent the results.

\section{RESULTS AND DISCUSSIONS}

Findings from OPAS survey in the descriptive analysis were presented. The mean represented the respondents' level of anxiety. Table I is the findings on Test Anxiety results, Table II is the findings on Communication Apprehension results and Table III is the findings on fear of negative evaluation results. The table showed low, moderate and high anxiety level from the survey. Mean scores 1 to 2 are low anxiety, mean score 3 is moderate and mean scores 4 and 5 are high anxiety.

TABLE 2 TEST ANXIETY RESUltS.

\begin{tabular}{|l|r|r|r|}
\hline \multicolumn{1}{|c|}{ Test Anxiety } & Mean & \multicolumn{1}{c|}{$\begin{array}{c}\text { Std. } \\
\text { Deviation }\end{array}$} & $\begin{array}{c}\text { Anxiety } \\
\text { level }\end{array}$ \\
\hline $\begin{array}{l}\text { I feel confident when I } \\
\text { present in my oral } \\
\text { presentation in the } \\
\text { classroom. }\end{array}$ & 3.86 & .918 & Moderate \\
\hline
\end{tabular}

TABLE 2 CONT.

\begin{tabular}{|l|r|r|l|}
\hline \multicolumn{1}{|c|}{ Test Anxiety } & Mean & \multicolumn{1}{|c|}{$\begin{array}{c}\text { Std. } \\
\text { Deviation }\end{array}$} & $\begin{array}{l}\text { Anxiety } \\
\text { level }\end{array}$ \\
\hline $\begin{array}{l}\text { I am usually at ease during } \\
\text { evaluations for my oral } \\
\text { presentation. }\end{array}$ & 3.70 & .893 & Moderate \\
\hline $\begin{array}{l}\text { I don't worry about making } \\
\text { mistakes in oral } \\
\text { presentation. }\end{array}$ & 3.64 & 1.072 & Moderate \\
\hline $\begin{array}{l}\text { When I'm on my way to do } \\
\text { an oral presentation in class, } \\
\text { I feel very sure and relaxed. }\end{array}$ & 3.51 & 1.002 & Moderate \\
\hline $\begin{array}{l}\text { I don't feel pressure to } \\
\text { prepare very well for oral } \\
\text { presentation. }\end{array}$ & 3.26 & 1.118 & Moderate \\
\hline $\begin{array}{l}\text { I am worried about the } \\
\text { consequences of failing my } \\
\text { oral presentation. }\end{array}$ & 3.15 & 1.309 & Moderate \\
\hline $\begin{array}{l}\text { I am afraid that my lecturer } \\
\text { is ready to correct every } \\
\text { mistake I make in an oral } \\
\text { presentation. }\end{array}$ & 2.92 & 1.064 & Low \\
\hline $\begin{array}{l}\text { I start to panic when I have } \\
\text { to speak without } \\
\text { preparation in an oral } \\
\text { presentation. }\end{array}$ & 2.62 & 1.232 & Low \\
\hline $\begin{array}{l}\text { I feel very self-conscious } \\
\text { (uncomfortable) about } \\
\text { doing the oral presentations } \\
\text { in front of other students. }\end{array}$ & 2.37 & 1.230 & Low \\
\hline
\end{tabular}

TABLE 3 COMMUNICATION APPREHENSION RESULTS

\begin{tabular}{|l|r|r|l|}
\hline Communication Apprehension & Mean & $\begin{array}{c}\text { Std. } \\
\text { Deviation }\end{array}$ & $\begin{array}{c}\text { Anxiety } \\
\text { level }\end{array}$ \\
\hline $\begin{array}{l}\text { It wouldn't bother me at all } \\
\text { to do more oral } \\
\text { presentations. }\end{array}$ & 3.67 & 1.259 & Moderate \\
\hline $\begin{array}{l}\text { I would not be nervous to } \\
\text { do an oral presentation. }\end{array}$ & 3.53 & 1.203 & Moderate \\
\hline $\begin{array}{l}\text { I can feel my heart } \\
\text { pounding when I'm going } \\
\text { to be called on for oral } \\
\text { presentation. }\end{array}$ & 3.32 & 1.223 & Moderate \\
\hline $\begin{array}{l}\text { I get nervous when I do an } \\
\text { oral presentation which I } \\
\text { haven't prepared in } \\
\text { advance. }\end{array}$ & 3.00 & 1.247 & Moderate \\
\hline $\begin{array}{l}\text { In oral presentation, I can get } \\
\text { so nervous I forget things I } \\
\text { know. }\end{array}$ & 2.93 & 1.417 & Low \\
\hline $\begin{array}{l}\text { I get nervous and confused } \\
\text { when I am presenting in my } \\
\text { oral presentation. }\end{array}$ & 2.70 & 1.102 & Low \\
\hline
\end{tabular}


i CONT.

\begin{tabular}{|l|r|r|l|}
\hline Communication Apprehension & Mean & $\begin{array}{c}\text { Std. } \\
\text { Deviation }\end{array}$ & $\begin{array}{c}\text { Anxiety } \\
\text { level }\end{array}$ \\
\hline $\begin{array}{l}\text { I tremble when I know that } \\
\text { I'm going to be called on } \\
\text { for oral presentation. }\end{array}$ & 2.53 & 1.156 & Low \\
\hline $\begin{array}{l}\text { I never feel quite sure of } \\
\text { myself when I am giving an } \\
\text { oral presentation in the } \\
\text { English language. }\end{array}$ & 2.51 & 1.203 & Low \\
\hline $\begin{array}{l}\text { I often feel like not going to } \\
\text { do my oral presentation. }\end{array}$ & 2.37 & .979 & Low \\
\hline
\end{tabular}

TABLE 4 FEAR OF NEGATIVE EVALUATION RESULTS.

\begin{tabular}{|l|r|r|l|}
\hline Fear of Negative Evaluation & Mean & $\begin{array}{c}\text { Std. } \\
\text { Deviation }\end{array}$ & $\begin{array}{c}\text { Anxiety } \\
\text { level }\end{array}$ \\
\hline $\begin{array}{l}\text { I don't understand why } \\
\text { some people get so upset } \\
\text { during the oral } \\
\text { presentation. }\end{array}$ & 3.59 & 1.103 & Moderate \\
\hline $\begin{array}{l}\text { I get upset when I don't do } \\
\text { my oral presentation well. }\end{array}$ & 3.45 & 1.179 & Moderate \\
\hline $\begin{array}{l}\text { I keep thinking that the } \\
\text { other students are better at } \\
\text { oral presentation than I am. }\end{array}$ & 3.42 & 1.154 & Moderate \\
\hline $\begin{array}{l}\text { I always feel that the other } \\
\text { students do the oral } \\
\text { presentation better than I } \\
\text { do. }\end{array}$ & 3.21 & 1.166 & Moderate \\
\hline $\begin{array}{l}\text { Even if I am well prepared } \\
\text { for oral presentation, I feel } \\
\text { anxious about it. }\end{array}$ & 2.93 & 1.171 & Low \\
\hline $\begin{array}{l}\text { I feel more tense and } \\
\text { nervous in my oral } \\
\text { presentation session than in } \\
\text { my other sessions. }\end{array}$ & 2.64 & 1.147 & Low \\
\hline $\begin{array}{l}\text { I am afraid that the other } \\
\text { students will laugh at me } \\
\text { when I present the oral } \\
\text { presentation session. }\end{array}$ & 2.45 & 1.202 & Low \\
\hline $\begin{array}{l}\text { It embarrasses me to } \\
\text { volunteer to do oral } \\
\text { presentation. }\end{array}$ & 2.18 & 1.183 & Low \\
\hline
\end{tabular}

Table 1 showed that 6 Test Anxiety statements out of 9 statements resulted in moderate anxiety mean score. Table II showed Communication Apprehension had equal number of statements that were moderate and low anxiety. Table III showed that five statements of low anxiety and four statements of moderate anxiety mean score in Fear of Negative Evaluation construct. Our findings show that more pre-service teachers faced test anxiety as compared to communication apprehension and fear of negative evaluation..

The mean score represented the moderate feeling in test anxiety would effect the pre-service in their oral performance. The pre-service faced more test anxiety probably because test effected on their result in oral performance. The result is assumed as important to them because they are able to serve in the job market if they get good result.

An important fact from this study is no pre-service teachers had high anxiety in oral performance survey. One of the reasons is because the TESL pre-service teachers would become English teachers that high anxiety in speaking the language is rare. Another reason might be the English lecturers are giving enough motivation for the pre-service teachers to speak. [14]opined unmotivated teachers were anxiety provoking for the students in foreign language learning. Thus, lecturers should give enough motivation to the pre-service teachers to speak in English without anxiety feeling.

\section{RECOMMENDATION FOR FURTHER RESEARCH}

Further studies are suggested to investigate the preservice teachers' causes of anxiety and the action plan for them to overcome or reduce anxiety in oral performance. Investigation on oral performance anxiety might use a strategy on the oral performance to lessen anxiety like Oral Performance in Islamic and Asian Civilisation (OPIAC) strategy.

\section{CONCLUSION}

Scholars begin to understand that anxiety has an important role in language learning especially in oral presentation. Oral presentation is part of professional requirement for the pre-service teachers. Pre-service teachers could easily get into the job market if they are competent presenters with less anxiety.

\section{REFERENCES}

[1] M. MoE, Malaysia Education Blueprint 2015-2025 (Higher Education). Putrajaya Malaysia: Kementerian Pendidikan Malaysia No. 2, Menara 2, Jalan P5/6, Presint 562200 Putrajaya Malaysia, 2015.

[2] M. L. Brown T, "The Effectiveness of verbal selfguidance as a transfer of training intervention: its impact on presentation performance, self-efficacy and anxiety. Innovations in Education and Teaching International," vol. 41, no. 3, pp. 256-70, 2004.

[3] W. F, "A Genre Approach To Oral Presentations," Internet TESL J., vol. 8, no. 7, 2002.

[4] A. A. HINDO, Cindy S.; GONZÁLEZ-PRENDES, "One-Session Exposure Treatment For Social Anxiety With Specific Fear Of Public Speaking," Res. Soc. Work Pract., vol. 21, no. 5, pp. 528-538, 2011.

[5] T. T. Krashen SD, "The Natural approach: Language Acquisition In The Classroom," Great Britain: Prentice Hall Europe, 1995, p. 185.

[6] C. J. Horwitz, Horwitz MB, "Foreign Language Classroom Anxiety,” Mod. Lang. J., vol. 70, no. 2, pp. 
125-32, 1986.

[7] B.-Z. M. Safir MP, Wallach HS, "Virtual Reality Cognitive-Behavior Therapy For Public Speaking Anxiety: One-year Follow Up," Behav. Modif., vol. 36, pp. 235-246, 2012.

[8] A. P. Price M, "Outcome Expectancy As A Predictor Of Treatment Response In Cognitive Behavioral Therapy For Public Speaking Fears Within Social Anxiety Disorder," Psychotherapy, vol. 49, no. 2, pp. 173-179, 2012.

[9] S. P. Finn AN, Sawyer CR, "Examining The Effect Of Eexposure Therapy On Public Speaking State Anxiety," Commun. Educ., vol. 58, no. 1, pp. 92-109, 2009.

[10] P. J, "SPSS Survival Manual: A Step By Step Guide To Data Analysis Using SPSS. 4 ed," New York, USA: Mc Graw Hill, 2010, p. 345.

[11] V. DAD, Surveys in Social Research, 5th Edition. Australia: Allen \& Unwin, 2002.

[12] M. P. George D, SPSS For Windows Step By Step: A Simple Guide And Reference 4ed. Boston: Allyn \& Bacon, 2003.

[13] W. A, "Learners' Perceptions Of The Benefits Of Voice Tool-Based Tasks On Their Spoken Performance," Gist Educ. Learn. Res. J., pp. 48-65,
2014.

[14] T. AR, "Foreign Language Anxiety In A New English Program In Thailand," Int. Educ. J. Comp. Perspect., vol. 3, no. 1, 20141. 